\title{
Video observations of the underside of arctic sea ice - features and morphology on medium and small scales
}

\author{
IRIS WERNER and FRANK LINDEMANN
}

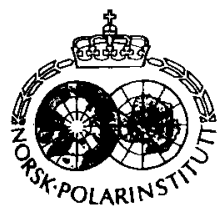

Werner, I. \& Lindemann, F. 1997: Video observations of the underside of arctic sea ice - features and
morphology on medium and small scales. Polar Research $16(1), 27-36$.

Morphological structures and the occurrence of sea-ice sediments and ice-related algae at the ice floe-water column interface were studied by video observations in summer 1995. Recordings at twelve stations in the northern Laptev Sea and the adjacent Arctic Ocean showed large variations. On a medium-scale (metres), level ice and deformed floes as well as whole rafted and stacked floes were found. At the underside of floes, small-scale structures (centimetres) such as bulges, depressions and holes were observed. The surface and sides of rafted floes sometimes had downward running grooves. Sediment inclusions occurred in diffuse or concentrated forms as well as in parallel streaks. Ice-related algae were visible as green areas at the underside of floes or as threads hanging into the water column. The distribution of sediments and algae was patchy. Some processes which might lead to the observed structures are suggested.

Iris Werner, Sonderforschungsbereich 313, Institute for Polar Ecology, Wischhofstr. 1-3, Geb. 12, D-24148 Kiel, Germany; Frank Lindemann, Geomar Research Centre for Marine Geosciences, Wischhofstr. 1-3, Geb. 4, D-24I48 Kiel, Germany.

\section{Introduction}

The Arctic Ocean is covered by a sea-ice area ranging from $7 \times 10^{6} \mathrm{~km}^{2}$ in the summer to $14 \times 10^{6} \mathrm{~km}^{2}$ in the winter (Maykut 1985). This ice cover is not homogeneous, but rather a mixture of different ice types, together with areas of open water. Microstructural differences exist between granular and congelation ice due to the type of ice growth (Eicken et al. 1995). Depending on the age and dynamics of the ice, a variety of thicknesses and structures occurs. First-year ice can commonly be separated from multi-year ice by means of microstructure and thickness (Gow \& Tucker 1990).

Conspicuous medium-scale structures on the surface of arctic ice floes include melt ponds (Nansen 1906; Langleben 1969; Morassutti \& LeDrew 1995; Ikävalko et al. 1996) as well as pressure ridges, hummocks and rubble fields (Conners et al. 1990; Gow \& Tucker 1990). These surface structures will not always be mirrored at the underside of the ice (Rothrock \& Thorndike 1980), as will be shown also by our video observations.

Various investigations of the underside of ice floes have been made, mostly by upward-looking sonar from submarines (Lyon 1961; Kozo \& Tucker 1974; Wadhams 1981; McLaren 1989; Key \& McLaren 1990). This method yields linear profiles which give information on ice draft, ridge keels and leads. By means of upward-looking sidescan sonar, Wadhams $(1978,1988)$ presented the first impressions of the three-dimensional morphology of under-ice structures on a large to medium scale. Information on medium-scale structures has also been provided by means of a scanning sonar mounted at the end of a metal bar and lowered through a hole in the ice (Johnsen 1989). However, these are all acoustic methods. The occurrence and distribution of algae (Horner et al. 1992; Gradinger 1996) and sediments (Barnes et al. 1982; Larssen et al. 1987) within the ice have been documented by core material which can deliver only a patchy account of a certain area of the floe underside. Very few visual impressions of the underside of the ice, photographed by divers, have been published (Reimnitz \& Dunton 1979; Reimnitz et al. 1987).

Here we present observations made by means of video recordings of the underside of arctic sea ice and describe medium- to small-scale morphological structures and features, including the 


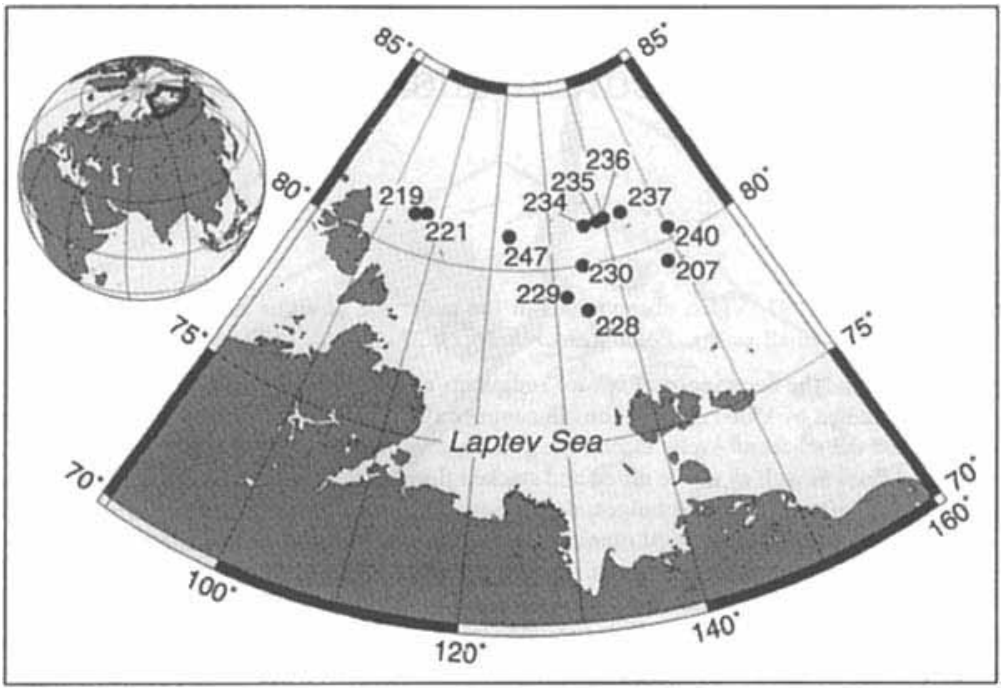

Fig. 1. Study area and location of ice stations during the expedition ARK XI/1 of the R/V POLARSTERN

(7.7.1995-20.9.1995). Station numbers are days of the year. occurrence and distribution of sea-ice sediments and ice-related algae.

\section{Material and methods}

This investigation was conducted during the expedition ARK XI/1 (7.7.95-20.9.95) with the German research icebreaker R/V POLARSTERN to the Laptev Sea and the adjacent Arctic Ocean. Firstyear ice (H. Eicken, pers. comm. 1996) was sampled at twelve stations (Fig. 1), and the core holes were subsequently used for making the video recordings.

The video system employed for the under-ice recordings was a Micro CTV colour camera (Benthos, Inc.) equipped with a $6 \mathrm{~mm}$ lens (water corrected dome) and automatic iris control, housed in a watertight aluminium case. The sensitivity of the camera is sufficient (minimum of 4.5 Lux) for under-ice recordings without artificial light. With the camera mounted on a manageable arm, recordings could be made from a straight upward to horizontal view under the ice as well as at a rotation of 360 degrees around the vertical core hole. The camera was connected to a S-VHS video recorder and monitor standing on the ice. The whole system was powered by a $800 \mathrm{~W}$ generator. The recordings covered an area of radius $10-20 \mathrm{~m}$ around the core hole.

The morphological structures recorded were divided into two size groups, medium- and small- scale structures. The medium-scale structures, relating to the morphology of whole floes, ranged in size from one to tens of metres. The small-scale structures, referring to features observed at the underside of level ice and at the sides and surfaces of deformed or rafted floes, ranged in size from centimetres to decimetres.

\section{Results and discussion}

The observed under-ice features are described in terms of medium- and small scale morphological structures (Table 1) and as different forms of sediment inclusions and ice-related algae (Table 2 ). The occurrence of a certain structure, as well as the combination of several structures, was variable. Every floe had a different under-ice scenario. The surface area chosen for under-ice video recordings was always quite flat and white and never in the vicinity of pressure ridges or sediment patches. In general, the snow thickness was less than $0.04 \mathrm{~m}$. Coverage with surface melt ponds varied between 20 and 50\% among the stations; the camera was usually deployed within $10 \mathrm{~m}$ of a pond.

\section{Medium-scale morphological structures}

Level-ice floes.-A continuous, undeformed sheet of level ice in all directions from the camera was 
Table 1. Medium- and small-scale morphological structures at the underside of arctic sea ice and on rafted ice material, observed by video recordings. $+++=$ frequent, $++=$ moderate, $+=$ rare, $-=$ not observed. Station numbers are days of the year.

\begin{tabular}{|c|c|c|c|c|c|c|c|c|c|c|}
\hline \multirow[b]{2}{*}{ Station } & \multirow{2}{*}{$\begin{array}{c}\text { Ice } \\
\text { Thickness } \\
\text { (m) }\end{array}$} & \multicolumn{3}{|c|}{ Medium-scale structures } & \multicolumn{6}{|c|}{ Small-scale structures } \\
\hline & & $\begin{array}{l}\text { Level } \\
\text { ice floe }\end{array}$ & $\begin{array}{l}\text { Deformed } \\
\text { floe }\end{array}$ & $\begin{array}{c}\text { Rafted } \\
\text { floe }\end{array}$ & Bulges & Depressions & Holes & Grooves & Cracks & $\begin{array}{l}\text { Fiaked off } \\
\text { spots }\end{array}$ \\
\hline 207 & 2.80 & - & - & +++ & - & + & - & ++ & - & - \\
\hline 219 & 1.65 & + & + & - & +++ & + & +++ & + & - & - \\
\hline 221 & 3.00 & - & ++ & + & - & + & - & + & + & - \\
\hline 228 & 1.50 & + & - & ++ & - & - & - & ++ & - & - \\
\hline 229 & 2.20 & ++ & + & - & - & ++ & +++ & + & + & - \\
\hline 230 & 2.30 & - & + & + & + & ++ & - & - & - & - \\
\hline 234 & 0.95 & +++ & - & - & +++ & +++ & - & - & + & + \\
\hline 235 & 1.35 & +++ & - & - & + & ++ & - & - & - & +++ \\
\hline 236 & 1.70 & - & +++ & - & ++ & ++ & - & - & - & ++ \\
\hline 237 & 1.30 & ++ & + & - & - & + & - & - & - & +++ \\
\hline 240 & 1.30 & $++t$ & - & - & - & +++ & + & - & - & - \\
\hline 247 & 1.55 & ++ & + & - & - & - & ++ & - & - & - \\
\hline
\end{tabular}

Table 2. Sediment inclusions and algae at the underside of arctic sea ice and on rafted ice material observed by video recordings. $+++=$ frequent,$++=$ moderate,$+=$ rare, $-=$ not observed. Station numbers are days of the year.

\begin{tabular}{|c|c|c|c|c|c|c|}
\hline \multirow[b]{2}{*}{ Station } & \multicolumn{4}{|c|}{ Sediment inclusions } & \multicolumn{2}{|c|}{ Algae } \\
\hline & Clouds & Patches & Dots & Streaks & Patches & Threads \\
\hline 207 & + & - & +++ & +++ & - & - \\
\hline 219 & - & - & + & - & +++ & - \\
\hline 221 & + & + & - & - & $++t$ & - \\
\hline 228 & - & - & +++ & ++ & - & - \\
\hline 229 & ++ & ++ & ++ & + & + & - \\
\hline 230 & - & - & + & - & - & - \\
\hline 234 & ++ & + & - & + & ++ & + \\
\hline 235 & - & - & - & - & ++ & ++ \\
\hline 236 & ++ & - & + & - & + & + \\
\hline 237 & + & - & + & - & + & +++ \\
\hline 240 & + & + & + & - & - & - \\
\hline 247 & - & - & - & - & - & - \\
\hline
\end{tabular}

observed only at three stations (Table 1). Another five stations had some parts level ice together with deformations or rafted ice at the underside. With the exception of one station (Stn. 229), all levelice floes had the typical thickness of undeformed arctic first-year ice of less than $2 \mathrm{~m}$ (Gow \& Tucker 1990). The underside of level-ice floes had a variety of small-scale structures (Fig. 2).

Deformed floes.-Deformations of the ice sheet with broken and sagging slabs (decimentres to metres in size) were observed at seven stations (Table 1). The video recordings show different structures ranging from one single buckled block to an extensive under-ice rubble field, including vertically oriented floes (Fig. 3). These structures are caused by compression and shear due to converging ice (Gow \& Tucker 1990). Deformed under-ice structures have often been described to be mirrored by similar expressions at the floe surface, i.e. by pressure ridge sails, hummocks or rubble fields (Connors et al. 1990; Gow \& Tucker 1990). The present observations contrast the view, as the floe surface directly above these deformed structures was always quite flat.

Rafted floes.-A very conspicuous scenario with entire floes rafted under a level floe was recorded at four stations (Table 1). Several layers of floes, each about 0.5 to $1 \mathrm{~m}$ thick, were stacked in a partly irregular manner (Fig. 4). A variety of 


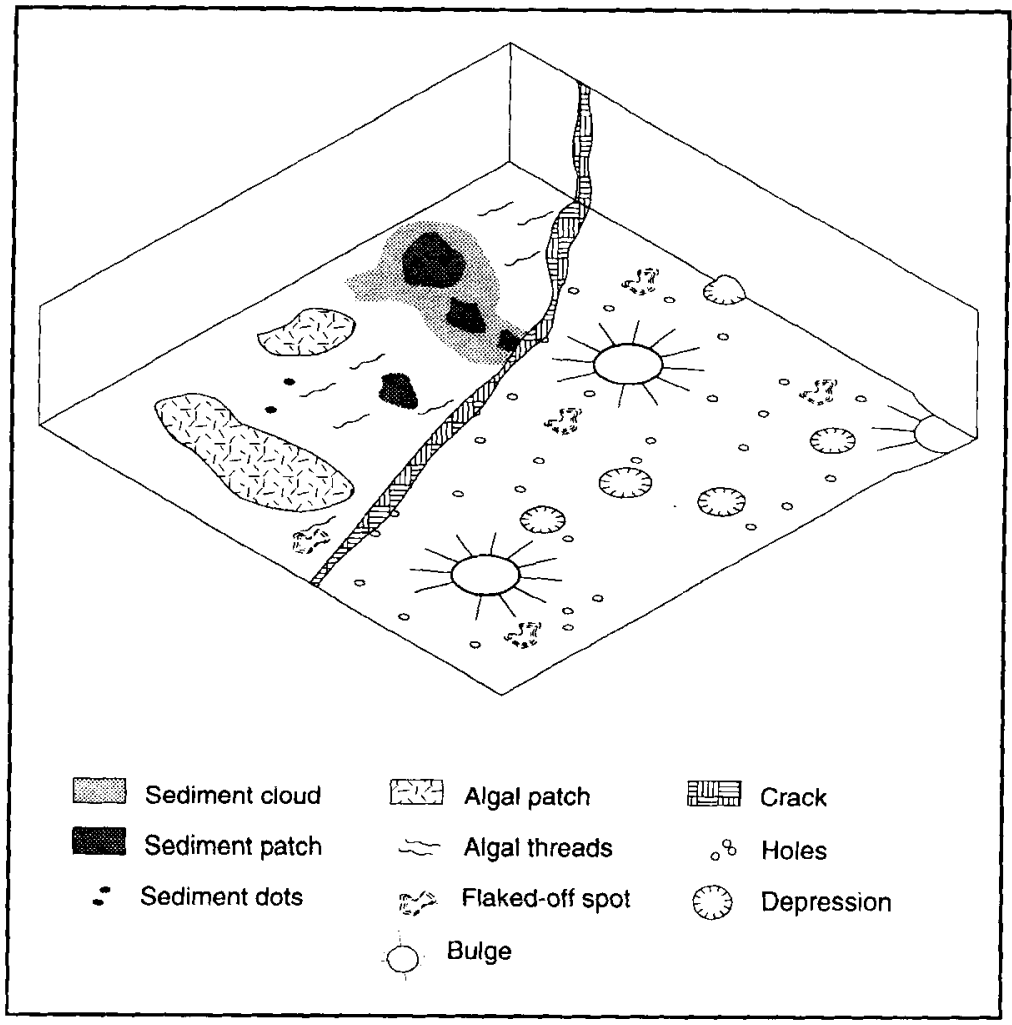

Fig. 2. Small-scale morphological structures, seaice sediments and ice-related algae at the underside of an arctic level-ice floe. Sketch without scale, for dimensions see text. cavities formed between these rafted floes. Rafting of floes has mainly been described for pancake and thin ice (Lange et al. 1989; Gow \& Tucker 1990), but there is also evidence in microstructural analyses of ice-cores from the Eurasian Basin for rafting of as many as three floes, each about $1 \mathrm{~m}$ thick, where gaps between floes were filled with granular ice (Pfirman et al. 1989). Ice thicknesses at stations with rafted floes in the present study were as great as $3 \mathrm{~m}$ (Table 1).

\section{Small-scale morphological structures}

Bulges and depressions.--Bulges at the underside of floes were observed at five stations (Table 1), mainly under level ice. These were several centimetres to decimetres in diameter, rarely being 1-2 metres, and protruding smoothly from the floe bottom into the water column (Fig. 2). Bulges were rare and random at some stations but densely packed and covered the entire underside of other floes. They usually occurred together with depressions, giving the whole underside of the floe an undulating appearance as described for multi-year floes (Kozo \& Tucker 1974; Key \& McLaren 1990). However, as the depressions also occurred at five additional stations where there were no bulges, these two structures are not necessarily coupled.

Bulges at the underside of arctic sea ice have already been described from upward-looking sidescan sonar images (Wadhams 1988; Wadhams $\&$ Martin 1990). These were of sizes from 10 to $50 \mathrm{~m}$ and were observed exclusively at the underside of multi-year ice. First-year ice appeared smooth and featureless on the sidescan images. It is possible that the small-scale undulations observed by video-recordings in the present study were too small to be resolved by the sonar techniques. Wadhams \& Martin (1990) suggest that the large bulges form during the melt-freeze cycle, together with similar large depressions, reflecting the surface melt pond topography. The structures observed in the present study were of much smaller dimensions, but might nevertheless 
Fig. 3. Video print of an underice rubble field (Stn. 207). The overlying floe is not shown in this figure. Thickness of the vertically oriented floe $0.5-1 \mathrm{~m} . \mathrm{V}=$ vertically oriented floe, $w=$ water column.

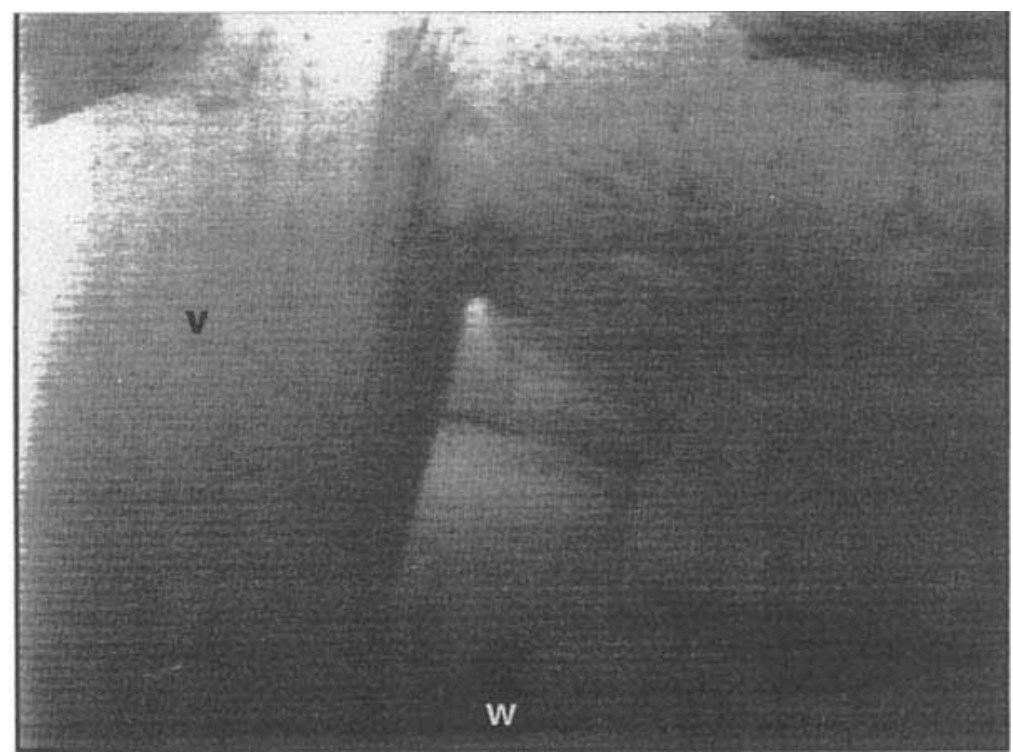

also be related to small-scale melting processes as indicated by the undulating appearance (Kozo \& Tucker 1974). There was no evidence at any of the stations for the formation of under-ice melt ponds, as previously described by Eicken (1994).

Holes.-Holes several centimetres in diameter were recorded at four stations (Table 1), but only on the underside of level ice (Fig. 2). The holes probably represent the ends of brine drainage channels, which usually have a diameter on the order of $5 \mathrm{~mm}$ (Gow \& Tucker 1990) but may also reach $10 \mathrm{~mm}$ (Eicken 1994) or 2-3 cm (own obs). There has also been speculation that the sides of the brine channels act as a wave-guide for solar radiation, resulting in a rapid development of larger thaw holes (Wadhams \& Martin 1990). Such thaw holes might then widen by further melting into the depressions described above.

Grooves.-Grooves at the sides or tilted surfaces of rafted floes were observed at five stations (Table 1). These structures were $\mathrm{v}$-shaped and several centimetres to decimetres deep. The grooves at the sides of floes were always vertically oriented, independent of the tilt angle of the rafted floe (Fig. 4). Therefore, they must have developed after the rafting process. Vertical grooves were often coupled with sediment streaks.
A second type of groove with a more rounded and wavy surface was observed at sloping upper surfaces of rafted floes. These structures are probably described here for the first time, and there is no good explanation of how they develop.

Cracks.-Cracks were observed in the underside of only three ice floes (Fig. 2 and Table 1). They seem to be a common feature for first-year ice and probably form due to mechanical stress by ice pressure (Wadhams 1988). Like under-ice deformations and rafted floes, cracks seen at the bottom of the ice were not matched by cracks at the top and therefore did not penetrate the full ice thickness. However, these partial-penetration cracks probably represent a significant source of weakness in the ice sheet.

Flaked-off spots.-Flaked-off spots appeared at the underside of four level-ice floes (Table 1). They had very irregular shapes and were several centimetres in size (Figs. 2 and 5). The spots looked as if several layers of the ice column had flaked off one after another. Often there were algal threads attached to the fringes of the flakedoff spots which were moving in the current. It seems likely that the dragging threads would enhance, or even cause, the process of ablation when they are torn from the ice. Another process which might play a role in the ablation process is 

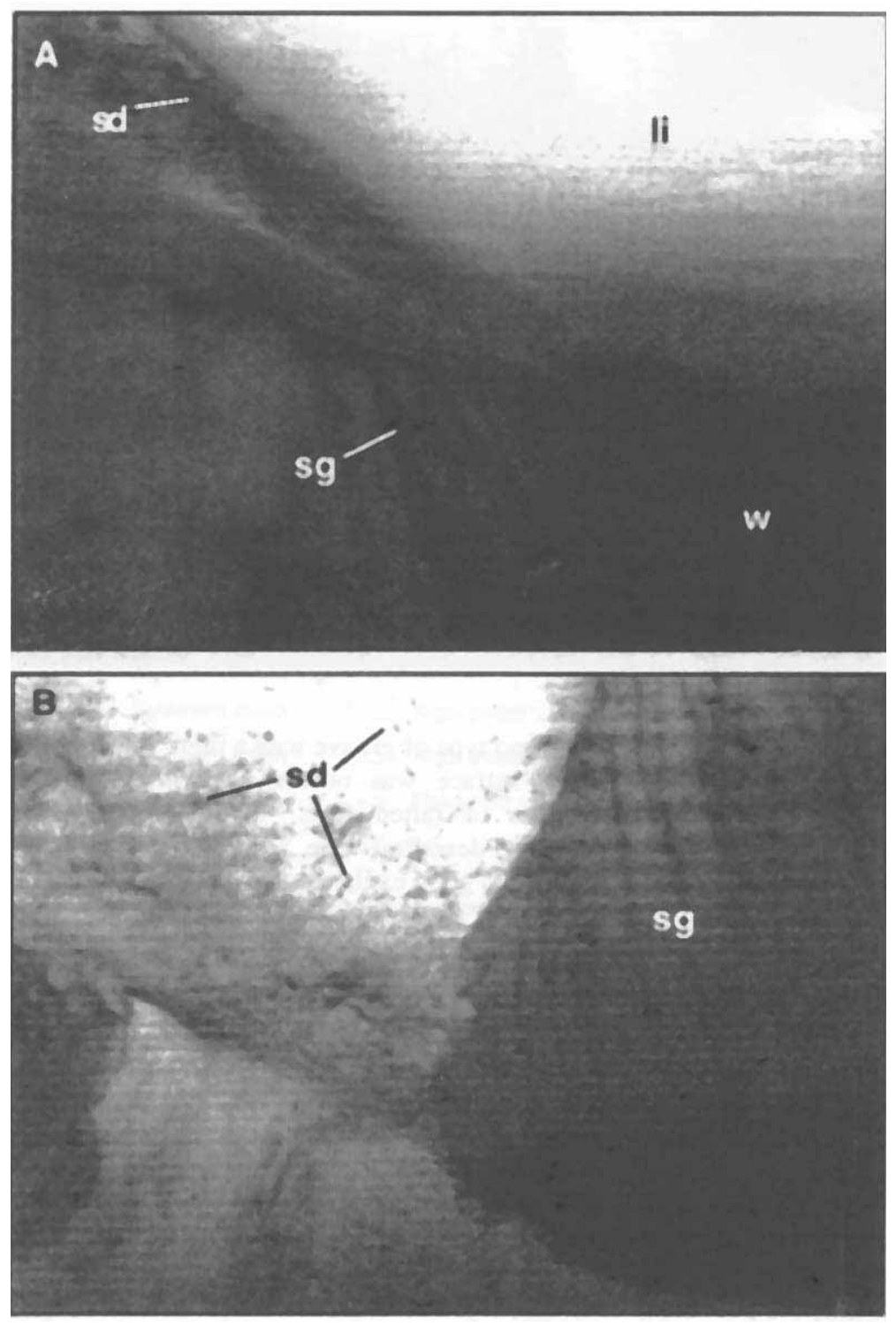

Fig. 4. Video prints of mediumand small-scale morphological structures and sea-ice sediments on rafted ice material beneath arctic sea ice. A. Whole rafted floe under level ice (Stn. 228), thickness of lower floe 1-2 m. B. Close-up vicw (Stn. 207), thickness of right floe $0.5-1 \mathrm{~m}$.

$\mathrm{Li}=$ overlying level-ice floe, $\mathrm{sd}=$ sediment dots,

sg $=$ sediment streaks and grooves, $w=$ water column.

the sloughing off of the lowermost ice-algal layer due to absorption of solar radiation and subsequent melting (Cota \& Horne 1989).

\section{Sea-ice sediments}

The transport of sediment incorporated into sea ice is important for the overall sediment budget in northern polar regions (Kempema et al. 1989).
Additionally, sediment inclusion affects biological activity by reducing light transmission through the ice (Barnes et al. 1982; Osterkamp \& Gosink 1984; Reimnitz \& Kempema 1987). Many chemically reactive pollutants, including synthetic organics, hydrocarbons and some radionuclides and trace metals become appreciably associated with particles when discharged into turbid aquatic environments (Olsen et al. 1982). Particles incorporated into sea ice could be transported 
Fig. 5. Video print of smallscale structures and algal threads at the underside of arctic sea ice (Stn. 237). $\mathrm{C}=$ camera arm, at = algal threads, fs $=$ flaked-off spots.

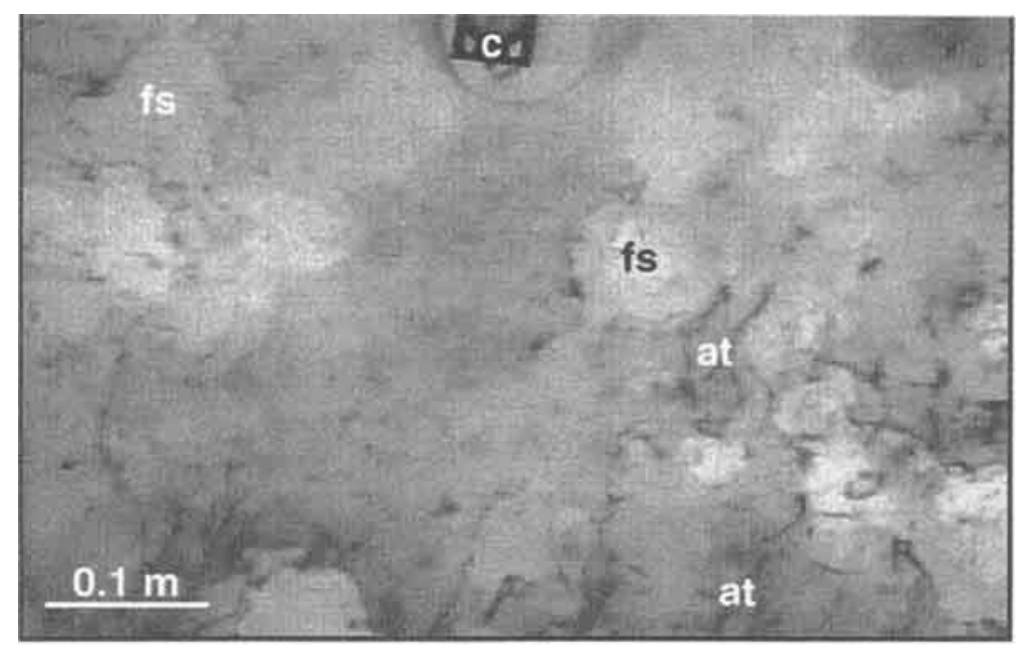

over long distances and released directly into surface waters where they may enter the food chain (Pfirman et al. 1995).

Clouds and patches.-Clouds and patches of brown to black discolourations (decimetres to metres) were observed at seven stations (Table 2). As indicated by analyses of ice-core material (Lindemann, unpubl.), these discolourations in the lowermost 10 to $20 \mathrm{~cm}$ of the ice floes are considered as sediment inclusions.

Some sediment inclusions appeared cloudy due to fine sediment particles being disseminated throughout the ice, as shown from drilled ice cores. Ice with this particle distribution is called turbid ice (Kempema et al. 1989). Sometimes the sediment concentrations increased toward the centre of the clouds forming black sediment patches of a few decimetres (Fig. 2).

A possible entrainment mechanism for these sediment inclusions is related to slushy soft-ice layers beneath a congealed ice canopy as described from diving observations by Reimnitz and Dunton (1979). They reported sediment-laden slush ice with a relief ranging between 0.5 to $1.5 \mathrm{~m}$ at the ice underside in early November. The site was revisited in early, March and the conspicuous, undulating slush-ice layer was still present beneath the solid, thick fast-ice canopy. An advancing freezing front might fill in gaps between the sediment-laden soft-ice billows with clean ice, resulting in a congealed, level-ice underside. Removal of the remaining slush ice by currents or ice movement, e.g. during ice break-up, might result in sediment clouds and patches on the ice underside as shown in our video records. Although entrainment by anchor ice could not be excluded, the cloudy appearance and the fine-grained sediments rendered this mechanism unlikely. Sediment inclusions derived from anchor ice would be patchy and contain a variety of sediment types and textures ranging from gravel to mud (Barnes et al. 1982).

Black sediment patches (centimetres to decimetres) without a fringe of turbid ice were also observed on the ice underside. Due to the small diameter and the well-defined edge of these patches, entrainment by rising anchor ice is probable. Other possible processes leading to sediment inclusions at the underside of ice floes are ice gouging, turning of floes, and waveinduced particle entrainment as proposed by Ackermann et al. (1994).

Dots.-Small sediment dots from millimetres to centimetres in diameter were observed at eight stations (Table 2). These isolated sediment inclusions were commonly located at the upper side and sides of rafted floes (Fig. 4). Their occurrence on the underside of floes was less frequent.

The sediment dots at the sides might result from sediments rinsed over the floe edge during ice rafting processes, followed by gravitationally governed sediment release. As a result, sediments would remain on the rough sides of rafted floes. 
At the upper side of rafted floes at Stn. 230, sediment dots were frozen onto the tip of a conelike structure, a few centimetres high. They are likely the result of some differential freezing and melting processes. One speculative explanation is that higher absorption of solar radiation at the ice surface caused the sediments to form cryoconite holes (=conus-shaped cavities in the ice surface) several centimetres deep before the floe was rafted. The meltwater from the cryoconite holes penetrated the ice beneath the holes, and when the floe was rafted beneath another, colder $\left(<0^{\circ} \mathrm{C}\right)$, more saline water infiltrated the more porous upper part of the ice and caused the less saline meltwater to freeze. As a result, a cone of hard freshwater ice would develop beneath a sediment dot. The more porous sea ice melted faster than the freshwater ice cone, which would be left with the sediment dot resting on the tip.

If the dots at the underside of floes were attributed to incorporation by frazil or anchor ice, sediment dots occurring in groups or clusters would be expected, but they commonly occurred isolated within a few square centimetres to decimetres. According to Wadhams \& Martin (1990), brine channels provide a possible downward pathway for meltwater. Surface melting may result in repositioning of surface material along pre-existing brine channels (Pfirman et al. 1989) and limited particle release due to brine channel enlargement (Pfirman et al. 1990). Therefore, it might be possible that the sediment dots mark the endpoints of brine channels at the ice underside due to "meltwater flushing" from the upper to the underside or by brine formation itself.

Streaks.-Exclusively at the sides of rafted floes, vertically oriented sediment streaks were observed at four stations (Table 2). The floes were irregularly oriented one to another, indicating that the streaks formed after the rafting processes. Often the streaks seemed to be located at the tip of v-shaped grooves (Fig. 4B). Although these sediment streaks have also been reported from diving observations in the Barents Sea (O.-J. Lønne pers. comm. 1996), there is no good explanation for their origin.

\section{Ice-related algae}

Ice-related algae play an important role as primary producers for the food web inside and under the arctic sea ice (Legendre et al. 1992). According to their position in or under the ice, they are classified into different communities (Ackley et al. 1979; Horner et al. 1992).

Patches.-Clearly visible green or brown patches (decimetres to metres) due to the occurrence of algae in the ice were observed at seven stations (Table 2). The colouration is probably a sign of high biomass, which often occurs in the lowermost centimetres of arctic sea ice, forming the bottom community (Horner et al. 1992; Legendre et al. 1992; Gradinger 1996). Algal patches were mainly observed on the underside of level ice (Fig. 2), except at Stns. 221 and 236, where algal patches occurred under deformed ice as well and mostly in areas of "clean" ice, probably because of light availability. However, the patches sometimes occurred adjacent to sediment-laden ice. This colouration was absent inside flaked-off spots, probably due to previous sloughing off of the algae (Cota \& Horne 1989), but surrounded them intensively.

Threads.-Distinct algal threads (several to tens of centimetres long) hanging from the ice underside into the water column were recorded at four stations (Table 2). They consisted mainly of the centric diatom Melosira arctica, which forms long chains. These algae belong to the sub-ice community (Horner et al. 1992). The threads were frequently attached to the ice underside at the fringes of flaked-off spots (Figs. 2 and 5) and were moving in the currents. At one station (Stn. 236), they were frozen horizontally onto the ice underside. At several stations, torn off shreds of algal aggregations were observed floating in the sub-ice currents or accumulating in clumps in depressions on the underside of the ice. Similar observations about $M$. arctica under first-year ice were reported from the Greenland Sea (Gutt 1995) and the central Arctic Ocean (Mel'nikov \& Bondarchuk 1987); however, in these areas the algal threads reached lengths up to $20 \mathrm{~m}$.

\section{Conclusions}

The undersides of arctic ice floes are highly structured and very variable in their appearance. Several features occur on medium- and small- 
scales which have significant implications (1) for sea-ice thickness distribution, e.g. by elevated thickness due to rafting and deformation processes, or by decreased thickness due to melting processes enhanced by sediments and algae; (2) for quantification of sea-ice sediments, since the occurrence of sediments at the ice underside can not be recorded by surface techniques, e.g. remote sensing or ship-born ice observations; and (3) for biological systems at the ice-water interface, e.g. by influencing the availability of light.

Future studies should therefore focus on a more systematic and quantitative approach toward the investigation of medium- and small-scale features of the underside of the ice and should combine methods from physical, geological and biological investigations.

Acknowledgements. - We are grateful to the captain and crew of R/V POLARSTERN, as well as to numerous colleagues for their help during the expedition ARK XI/1. We would also like to thank the members of the ice working group for assistance during field work, in particular $\mathrm{H}$. Eicken for organizing this crowd. Special thanks are due to K.-U. Evers and P. Jochmann for technical support. The manuscript benefited substantially from the constructive comments made by $\mathbf{R}$. Gradinger, $\mathrm{R}$. Horner and E. Reimnitz, as well as by three anonymous referees. The study was supported by the German Ministry of Science and Technology (grant no. 52540030G0517A). This is contribution No. 300 of the Sonderforschungsbereich 313, University of Kiel.

\section{References}

Ackermann, N. L., Shen, H. T, \& Sanders, B. 1994: Experimental studies of sediment enrichment of Arctic ice covers due to wave action and frazil entrainment. $J$. Geophys. Res. 99 (C4), 7761-7770.

Ackley, S. F., Buck, K, R. \& Taguchi, S. 1979: Standing crop of algae in the sea ice of the Weddell Sea region. Deep Sea Res. 26 (A), 269-281.

Barnes, P. W., Reimnitz, E. \& Fox, D. 1982: Ice rafting of finegrained sediment, a sorting and transport mechanism. $J$. Sediment. Petrol. 52 (2), 493-502.

Connors, D. N., Levine, E. R. \& Shell, R. R. 1990: A smallscale under-ice morphology study in the High Arctic. Pp. 145-151 in Ackley, S. F. \& Weeks, W. F. (eds.): Sea ice properties and processes. CRREL-Monograph, 90-1, Hanover, New Hampshire.

Cota, G. F. \& Horne, E. P. W. 1989: Physical control of arctic ice algal production. Mar. Ecol. Prog. Ser. 52, 111-121.

Eicken, H. 1994: Structure of under-ice melt ponds in the central Arctic and their effect on the sea-ice cover. Limnol. Oceanogr. 39 (3), 682-694.

Eicken, H., Lensu, M., Leppäranta, M., Tucker, W. B. III., Gow, A. J. \& Salmela, O. 1995: Thickness, structure and properties of level summer multiyear ice in the Eurasian sector of the Arctic Ocean. J. Geophys. Res. 100 (C11), 22697-22710.

Gow, A. J. \& Tucker, W. B. III. 1990: Sea ice in the polar regions. Pp. 47-122 in Smith, W. O., Jr. (ed.): Polar Oceanography Part A Physical Science. Academic Press, Inc., San Diego.

Gradinger, R. 1996: Occurrence of an algal bloom under Arctic pack ice. Mar. Ecol. Prog. Ser. 131, 301-305.

Gutt, J. 1995: The occurrence of sub-ice algal aggregations off northeast Greenland. Polar Biol. 15, 247-252.

Horner, R., Ackley, S. F., Dieckmann, G. S., Gulliksen, B., Hoshiai, T., Legendre, L., Mel'nikov, I. A., Reeburgh, W. S., Spindler, M. \& Sullivan, C. W. 1992: Ecology of sea ice biota 1. Habitat, terminology, and methodology. Polar Biol. $12,417-427$.

Ikävalko, J., Thomsen, H. A. \& Carstens, M. 1996: A preliminary study of NE Greenland shallow meltwater ponds with particular emphasis on loricate and scale-covered forms (Choanoflagellida, Chrysophyceae sensu lato, Synurophyceae, Heliozoea), including the descriptions of Epipyxis thamnoides, sp. nov, and Pseudokephyrion poculiforme sp. nov. (Chrysophyceae). Arch. Protistenkd. 147, 29-42.

Johnsen, A. S. 1989: Relations between top and bottom ice topography using a scanning sonar. Pp. $77-86$ in POAC 89, The 10th International Conference on Port and Ocean Engineering under Arctic Conditions, Vol. 1, Luleå, Sweden.

Kempema, E. W., Reimnitz, E. \& Bames, P. 1989: Sea ice sediment entrainment and rafting in the Arctic. J. Sediment. Petrol. 59 (2), 308-317.

Key, J. \& McLaren, A. S. 1990: Periodicities and keel spacings in the under-ice draft distribution. Pp. 156-160 in Ackley, S. F. \& Weeks, W. F. (eds.): Sea ice properties and processes. CRREL-Monograph, 90-1, Hanover, New Hampshire.

Kozo, T. L. \& Tucker, W. B. 1974: Sea ice bottomside features in the Denmark Strait. J. Geophys. Res. 79 (30), 4505-4511.

Lange, M. A., Ackley, S. F., Wadhams, P., Dieckmann, G. S. \& Eicken, H. 1989: Development of sea ice in the Weddell Sea. J. Glaciol. 12, 92-96.

Langleben, M. P. 1969: Albedo and degree of puddling of a melting cover of sea ice. J. Glaciol. 8, 407-412.

Larssen, B. B., Elverhøi, A. \& Aagaard, P. 1987: Study of particulate material in the Fram Strait - a contribution to paleoclimatic research? Polar Res. 5, 313-315.

Legendre, L., Ackley, S. F., Dieckmann, G. S., Gulliksen, B., Horner, R., Hoshiai, T., Mel'nikov, I. A., Reeburgh, W. S., Spindler, M. \& Sullivan, C. W. 1992: Ecology of sea ice biota 2. Global significance. Polar Biol. 12, 429-444.

Lyon, W. K. 1961: Ocean and sea-ice research in the Arctic Ocean via submarine. Trans. N.Y. Acad. Sci., srs 2 (23), $662-674$

Maykut, G. A. 1985: The ice environment. Pp. 21-82 in Horner, R. (ed.): Sea ice biota. CRC Press, Boca Raton, Florida.

McLaren, A. S. 1989: The under-ice thickness distribution of the Arctic Basin as recorded in 1958 and 1970. J. Geophys. Res. 94 (C4), 4971-4983.

Mel'nikov, I. A. \& Bondarchuk, L. L. 1987: Ecology of mass accumulations of colonial diatom algae under drifting Arctic ice. Oceanol. 27 (2), 233-236

Morassutti, M. P. \& LeDrew, E. F. 1995: Melt pond data set for use in sea-ice and climate related studies. Digital data available online [nsidckryos.colorado.edu]. National Snow and Ice Data Center, Boulder, Colorado. 
Nansen, F. 1906: Protozoa on the ice floes of the North Polar Sea. Pp. 1-22 in Nansen, F. (ed.): The Norwegian North Polar Expedition 1893-1896, Scientific Results. New York.

Olsen, C. R., Cutshall, N. H. \& Larsen, I. L. 1982: Pollutant particle associations and dynamics in coastal marine environments: a review. Mar. Chem. 11, 501-533.

Osterkamp, T. E. \& Gosink, J. P. 1984: Observations and analyses of sediment-laden sea ice. Pp. 73-93 in Barnes, P. W., Schell, D. M. \& Reimnitz, E. (eds.): The Alaskan Beaufort Sea: ecosystems and environments. Academic Press, Orlando.

Pfirman, S., Wollenburg, I., Thiede, J. \& Lange, M. A. 1989 Lithogenic sediment on Arctic pack ice: potential aeolian flux and contribution to deep sea sediments. Pp. 468-493 in Leinen, M. \& Sarnthein, M. (eds.): Paleoclimatology and paleometeorology: modern and past patterns of global atmospheric transport. NATO ASI Series C 308, Kluwer, Dordrecht.

Pfirman, S., Lange, M. A., Wollenburg, I. \& Schlosser, P. 1990: Sea ice characteristics and the role of sediment inclusions in deep-sea deposits: Arctic - Antarctic comparison. Pp. 187-211 in Bleil, U. \& Thiede, J. (eds.): Geological History of the Polar Oceans: Arctic versus Antarctic. NATO ASI Series C 308, Kluwer, Dordrecht.

Pfirman, S., Eicken, H., Bauch, D. \& Weeks, W. F. 1995: The potential transport of pollutants by Arctic sea ice. Sci. Total Environ. 159, 129-146.
Reimnitz, E. \& Dunton, K. 1979: Diving observations of the soft ice layer under the fast ice at DS-11 in the Stefansson Sound Boulder Patch. Pp. 210-230 in Environmental Assessment of the Alaskan Continental Shelf: Principal investigators' annual reports 9. Nat. Ocean. Atmos. Admin., Boulder, Colorado.

Reimnitz, E. \& Kempema, E. W. 1987: Field observations on slush ice generated during freeze-up in Arctic coastal waters. Mar. Geol. 77, 219-231.

Reimnitz, E., Kempema, E. W. \& Barnes, P. W. 1987: Anchor ice, seabed freezing, and sediment dynamics in shallow Arctic seas. J. Geophys. Res. 92 (C13), 14671-14678.

Rothrock, D. A. \& Thorndike, A. S. 1980: Geometric properties of the underside of sea ice. J. Geophys. Res. 85 (C7), 3955-3963.

Wadhams, P. 1978: Sidescan sonar imagery of sea ice in the Arctic Ocean. Can. J. Rem. Sens. 4, 161-173.

Wadhams, P. 1981: Sea-ice topography of the Arctic Ocean in the region $70^{\circ} \mathrm{W}$ to $25^{\circ} \mathrm{E}$. Phil. Trans. Roy. Soc. A302, 45-85.

Wadhams, P. 1988: The underside of Arctic sea ice imaged by sidescan sonar. Nature 333, 161-163.

Wadhams, P. \& Martin, S. 1990: Processes determining the bottom topography of multi-year Arctic sea ice. Pp. 136-141 in Ackley, S. F. \& Weeks, W. F. (eds.): Sea ice properties and processes. CRREL-Monograph, 90-1, Hanover, New Hampshire. 